\title{
BCR/FGFR1 Fusion Gene
}

National Cancer Institute

\section{Source}

National Cancer Institute. BCR/FGFR1 Fusion Gene. NCI Thesaurus. Code C99311.

A fusion gene that results from a chromosomal translocation $t(8 ; 22)(p 11 ; q 11)$ that fuses exon 4 of the BCR gene to exon 9 of the FGFR1 gene. This rearrangement is associated with 8p11 myeloproliferative disorder. 